\title{
IS THERE A ROLE FOR MONETARY AGGREGATES IN THE CONDUCT OF MONETARY POLICY?
}

Arturo Estrella

Frederic S. Mishkin

Working Paper 5845

\author{
NATIONAL BUREAU OF ECONOMIC RESEARCH \\ 1050 Massachusetts Avenue \\ Cambridge, MA 02138 \\ November 1996
}

We thank Ben McCallum, participants at the Swiss National Bank's 1996 Gerzensee conference, and participants at a seminar at the Federal Reserve Bank of New York for their helpful comments, and Betsy Reynolds for her research assistance. Any views expressed in this paper are those of the authors only and not those of Columbia University, the National Bureau of Economic Research, the Federal Reserve Bank of New York or the Federal Reserve System. This paper is part of NBER's research program in Economic Fluctuations and Growth and Monetary Economics.

(C) 1996 by Arturo Estrella and Frederic S. Mishkin. All rights reserved. Short sections of text, not to exceed two paragraphs, may be quoted without explicit permission provided that full credit, including $\mathbb{C}$ notice, is given to the source. 
Is There a Role for Monetary Aggregates

In the Conduct of Monetary Policy?

Arturo Estrella and Frederic S. Mishkin

NBER Working Paper No. 5845

November 1996

JEL Nos. E52

Economic Fluctuations and Growth and Monetary Economics

\section{ABSTRACT}

We examine the potential policy role of monetary aggregates by attempting to use them as effectively as possible in the analysis of empirical relationships. We consider three possible roles: as information variables, as indicators of policy actions and as instruments in a policy rule. These require successively stronger and more stable relationships between the aggregates and the final policy targets. Our results show that in the United States since 1979, the monetary aggregates fall considerably short of those requirements, and results with German M3 are hardly more favorable. We also investigate whether empirical relationships are not reflective of causal relationships because of the use of these variables in counter cyclical policy. The results are reasonably consistent with that notion in the case of interest rates, but not in the case of the aggregates.

Arturo Estrella

Federal Reserve Bank of New York

33 Liberty Street

New York, NY 10045
Frederic S. Mishkin

Federal Reserve Bank of New York 33 Liberty Street

New York, NY 10045

and NBER

frederic.mishkin@frbny.sprint.com 


\section{Introduction}

The economics literature contains prescriptions for the use of monetary aggregates in macroeconomic policy that range from exclusive focus on the aggregates to their almost complete disregard. Since the 1980 s, advocates of a central role for monetary aggregates have been confronted with a deterioration of the traditional relationships between money and policy targets. These changes may be partly explained by policy regime shifts and partly by financial innovation, but the consequent fluctuations in money velocity cannot be fully explained by reference to these factors.

In this paper, we examine the potential policy role of monetary aggregates by attempting to use them as effectively as possible, but without imposing strong priors about what their role should be. We look at some recent proposals for the use of monetary aggregates in formal rules and perform empirical tests of the strength and stability of the empirical relationships that those rules presuppose. More generally, we ask what role the aggregates can have even if the approach to policy is more eclectic than that implied in these recent proposals.

We see three potential uses for monetary aggregates. First, the aggregates may be used as information variables to provide a guide for the conduct of monetary policy. Such an informal role places only minimal demands on the aggregates, concerning mainly their informational content. Second, the aggregates could be used to signal the intentions of the central bank so as to make it accountable for carrying out policies that are consistent with its basic mandates and to enhance its credibility and the public's expectations of the attainment of its goals. The requirements imposed on the aggregates by this view are more demanding. 
If the central bank is compelled to act on the basis of this information, the relationships would have to be much tighter than if they are used in a loose, purely discretionary way.

The third possible role for the aggregates is in the context of a policy rule, such as the McCallum (1988) proposal for using the monetary base to target nominal income growth. The basic structure of the McCallum rule has been analyzed and extended in the recent literature, for example, by Judd and Motley (1991), Hess, Small and Brayton (1993), and Feldstein and Stock (1994). These rules pose the greatest demands on the performance of the aggregates, both as informational variables, as described earlier, and in terms of stable causal relationships with the ultimate policy goals.

Section 2 of the paper discusses the choice of monetary aggregates and targets for monetary policy. In section 3 of the paper, we formulate a theoretical model that establishes conditions under which a rule such as McCallum's is optimal. The analysis suggests ways to improve on the rule while retaining its general form. In section 4 , we turn to the empirical analysis of the relationships between money and nominal income and between money and inflation that need to hold if the aggregates are to be successfully used in any of the ways mentioned above. We focus on the monetary base, which is McCallum's (1988) preference, and on M2, which was advocated by Feldstein and Stock (1994). Some results for M1 are also included in the appendix. This paper differs from most previous work in this literature in that we rely primarily on monthly data to estimate the equations involving money, income and inflation. This is accomplished by using the Commerce Department/Conference Board index of coincident indicators to proxy for real income and the consumer price index as a 
measure of prices. The use of these series provides a richer sample and, as the appendix shows, the results are largely consistent with those obtained with quarterly data.

In section 5 we look at the performance of the base and of M2, in both cases adjusted by incorporating the improvements suggested by the analysis of section 3 . Section 6 describes the results of decomposing velocity into spectral components corresponding to low, medium (business cycle) and high frequency cycles. The instability of velocity seems to be concentrated in the low frequency cycles, and this information is used in reassessing the relationships between money, inflation and nominal income.

As a separate benchmark for the performance of the aggregates, we examine in section 7 the relationship between interest rates, inflation and nominal income. In our estimates, interest rates do not seem to outperform the monetary aggregates. However, we provide some evidence that their poor apparent performance may be explained by their use as instruments of countercyclical monetary policy.

Since economists and policymakers in Germany are more likely supporters of monetary aggregates than those in the United States, we repeat in section 8 some of the analysis of sections 4-7 with German data. We focus on the informational content of M3 for growth and inflation in westem Germany.

Section 9 concludes that the empirical relationships involving monetary aggregates, nominal income, and inflation are not sufficiently strong and stable in the United States to support an important role in policy. Empirical support for interest rates in a similar context is not obvious either, but their poor performance may be explained by their use in practice as policy instruments over the estimation period. 


\section{Policy Evaluation and the Choice of Target}

McCallum (1988) and most of the papers that follow up on his work use a simulationbased approach to evaluate policy rules. ${ }^{1}$ In the usual implementation, series "realizations" of the target variable, for example the log of nominal GDP, are simulated by incorporating a given policy rule in a given macroeconomic model, for instance, a VAR, a Keynesian or classical model. The mean squared deviation of the simulated series from its target level is then used as the criterion to gauge the usefulness of the rule. McCallum focuses on the comparison of mean squared errors from different rule-model combinations as a relative measure of usefulness of different counterfactual rules. Others, for example, Feldstein and Stock (1994), emphasize also the comparison of counterfactual rules with the observed series for the target variable in an attempt to gauge the potential improvement from using the rules.

Although attractive and possibly informative, the simulation approach suffers from some serious drawbacks. First, it is clear that the method is subject to the Lucas critique, even though the magnitude of this problem is not necessarily clear. ${ }^{2}$ Second, the rules are tested in the context of specific macroeconomic models, which may or may not be accurate representations of reality, whether or not there is a policy change. McCallum's solution to this issue is to use a wide range of models, that is, to perform sensitivity analysis with respect to the choice of model. This solution certainly helps increase the credibility of the results, but it presupposes that the choice of models is sufficiently broad and that the results

1 For example, Judd and Motley (1991), Hess, Small and Brayton (1993) and Feldstein and Stock (1994).

2 A useful discussion of the tradeoffs involved in using forecasting models for policy analysis is found in Sims (1986). 
in fact turn out not to be sensitive to the choice of model. Hess, Small and Brayton (1993), for example, have challenged the validity of such claims.

A third major problem is the comparison of simulation-based results with the actual series for the target variable, as in Feldstein and Stock (1994). The simulation results are invariably derived from a model that necessarily imposes strong simplifying assumptions. In addition, the policy rules are chosen, formally or informally, to optimize with respect to a particular mean squared deviation criterion within the data sample, whereas actual policy may have had a very different goal (price stability, for example).

Our approach in this paper to the evaluation of policy rules focuses on the assumptions underlying the rules. We ask: under what conditions is a policy rule like McCallum's optimal or -- more loosely -- when does it make sense? Not only is this of interest in its own right, but by analyzing the optimal rule, we can see how a monetary aggregate can be adjusted to use it more effectively as an information variable. Thus, in section 3 we develop a model under which a rule like McCallum's is optimal and examine the empirical support for the model. More generally, starting in section 4, we look at empirical relationships that should be strong and stable if a policy based on controlling monetary aggregates is to be successful. The move from our empirical analysis to our conclusions seems much less heroic than the leap between the counterfactual simulation models and reality in the papers in the McCallum tradition.

A somewhat related issue is the choice of policy target. McCallum (1988) and Feldstein and Stock (1994) advocate nominal income targeting. Others, including lawmakers and policymakers, have argued for price stability or inflation targeting, and Taylor (1993) 
has suggested a weighted average of inflation and income targets. Clearly, the results of the analysis are likely to depend on the choice of target variable.

In this paper, we focus mostly on nominal income targeting and price stability. Although we believe that price stability should be primary goal of monetary policy, we emphasize income targeting here because it is with regard to this variable that McCallum and others have made their claims. It is not clear in principle, however, that monetary policy can successfully rely on targeting nominal income without concerning itself with the breakdown into real growth and inflation. The emphasis on price stability in the Federal Reserve Act and in the current policy consensus seems to require a closer look at this breakdown. Reliance on aggregate nominal growth only would seem to require, at minimum, some concomitant view about a stable relationship between the aggregate nominal measure and its price component.

Another aspect of the choice of goal is whether it suffices to hit the target on average or whether policy should be countercyclical in the sense of staying close to the target levels. Thus, Milton Friedman has presented a cogent case for "first moment monetarism": arguing in Friedman (1968) for a k-percent money growth rule that keeps inflation on course over the long term and arguing against countercyclical smoothing in Friedman (1953). McCallum (1988) and Feldstein and Stock (1994), in contrast, advocate a "second moment monetarism", in which the goal is to minimize squared deviations of the target variable from its chosen path. The requirements of this second moment variety are clearly more demanding than those of the first. It is not surprising that the long-term average view is much less controversial in the profession than the short-term smoothing approach. 


\section{Optimal Policy and the McCallum Rule}

The potential usefulness of McCallum's (1988) rule may be justified and interpreted in various ways. In this section, we develop a parsimonious framework in which a monetary policy rule of the McCallum type is optimal. This approach is then used to suggest possible improvements in the rule. This also has the advantage that it suggests how a monetary aggregate can be adjusted to provide empirical testing of the rule, which is conducted in section 5 .

Previous research has been largely silent on the issue of the theoretical justification of money-based rules. The arguments given are generally informal, for example, in McCallum (1988) and Judd-Motley (1991), and the justification provided is typically based on artificial simulation results. Feldstein and Stock (1994) do calculate the optimal policy rule in a general vector autoregression context, but they too rely on simulations as the primary basis for their policy conclusions. Here, we connect these two approaches by deriving a policy rule which is formally similar -- under some conditions identical -- to that of McCallum.

Our model is based on the following assumptions. First, we use the identity associated with the quantity theory: nominal income equals money times velocity. Since this relationship may be viewed as the definition of velocity, it presupposes very little structure. Second, we assume that money is exogenous in the sense that its growth rate can be determined independently of current-period information. Third, we assume that velocity in the current period is unknown, but that the optimal prediction of velocity can be adequately characterized by a univariate ARIMA model. Fourth, we assume that the policy objective is 
to minimize the mean squared deviations of nominal income from a pre-specified target path. This objective is consistent with the analysis of all the papers cited in the previous paragraph. The quantity theory, in log-difference form, may be expressed as:

$$
\Delta x_{t}=\Delta m_{t}+\Delta v_{t}
$$

where $\mathrm{x}$ is the $\log$ of nominal income, $\mathrm{m}$ is the $\log$ of money, and $\mathrm{v}$ is the $\log$ of money velocity. The process for velocity is assumed to have an ARIMA specification. For convenience, this ARIMA relationship is written in the form:

$$
\Delta v_{t}=a(L) \Delta v_{t-1}+u_{t}+b(L) u_{t-1}
$$

where $u$ is white noise. The objective function is to minimize the mean squared deviation of nominal income $\left(x_{j}\right)$ from its target level $\left(x^{*}\right)$, conditional on the information available at time t.

To derive the policy rule, first write

$$
\Delta v_{t}=E_{t-1} \Delta v_{t}+u_{t}
$$

where $\mathrm{E}_{\mathrm{t}}$ represents the expectation based on information available at time $\mathrm{t}$. Combining equations (1) and (3), and defining $x_{t}^{*}$ as the target nominal income in period $t$, we obtain

$$
\Delta x_{\varepsilon}^{*}-\Delta x_{t}=\Delta x_{t}^{*}-\Delta m_{t}-E_{t-1} \Delta v_{t}-u_{t}
$$

and, rearranging terms, 


$$
x_{t}^{*}-x_{t}=x_{t}^{*}-x_{t-1}-\Delta m_{t}-E_{t-1} \Delta v_{t}-u_{t}
$$

Since $u_{t}$ is orthogonal to all the other terms in the right hand side of equation (4), which are either policy choices or are predetermined as of time $t$, the conditional variance of (4) is given by

$$
V_{t-1}\left(x_{t}^{*}-x_{t}\right)=V_{t-1} w_{t}+V_{t-1} u_{t}
$$

where

$$
w_{t} \equiv x_{t}^{*}-x_{t-1}-\Delta m_{t}-E_{t-1} \Delta v_{t}
$$

Thus, the conditional variance of (4) is minimized by setting $w_{t}=0$, that is, by applying a money supply rule of the form

$$
\Delta m_{t}^{*}=\Delta x_{t}^{*}-E_{t-1} \Delta v_{t}+x_{t-1}^{*}-x_{t-1}
$$

The ARIMA representation (2) for $\Delta \mathrm{v}_{\mathrm{t}}$ implies that

$$
E_{t-1} \Delta v_{t}=a(L) \Delta v_{t-1}+b(L) u_{t-1}
$$

Substituting (7) into (6), and noting from (4) and (5) that $w_{t}=0$ implies that $u_{t}=-\left(x_{t}{ }^{*}-x_{v}\right)$, produces the optimal monetary policy rule

$$
\Delta m_{t}^{*}=\Delta x_{t}^{*}-a(L) \Delta v_{t-1}+(1+b(L))\left(x_{t-1}^{*}-x_{t-1}\right)
$$

Example 1: If the lag polynomials in the ARIMA expression for $\Delta v_{1}$ are of the form 


$$
a(L)=\frac{1}{n} \sum_{j=0}^{n-1} L^{j}
$$

that is, the autoregressive part consists of a simple average of lagged $\Delta v_{t}$, and if $b(L)=\beta, a$ constant, then the optimal rule (8) becomes

$$
\Delta m_{t}^{*}=\Delta x_{t}^{*}-\overline{\Delta v_{t-1}}+(1+\beta)\left(x_{t-1}^{*}-x_{t-1}\right)
$$

where

$$
\overline{\Delta v}_{t}=\frac{1}{n} \sum_{j=0}^{n-1} \Delta v_{t-j}=\frac{1}{n}\left(v_{t}-v_{t-n}\right) .
$$

With $n$ corresponding to 48 months, (9) is the rule suggested by McCallum (1988). ${ }^{3}$

The resulting rule is plausible, but does not fit the data well. The first equation in table 1 provides an empirical estimate of $\beta$, which is the only parameter in the McCallum rule, obtained by estimating the constrained form of the ARIMA equation (2) over the period from March 1963 to December 1995. As noted in the introduction, we use the index of coincident indicators and the consumer price index as monthly measures of real activity and prices. McCallum (1988) does not estimate this parameter, but uses a range of values $0 \leq \lambda=1+\beta \leq .5$ in his simulations. Our estimate of $\lambda=1+\beta$ is 1.175 , which is substantially larger than any of McCallum's assumed values. In fact, when inserted in the monetary rule,

3 McCallum uses quarterly data, in which case $n=16$. Also, in more recent papers, e.g., McCallum (1993a, 1994), he has considered variants of this rule in which the target is defined in terms of nominal income growth, rather than its level. The available simulation evidence for these variants is not as extensive as for the levels version, but McCallum (1993b) finds that it works better in Japan with an interest rate instrument. 
this estimate implies that the reaction to a gap between actual and target nominal income in the previous period is larger than the gap itself. ${ }^{4}$

The ARIMA formulation may be relaxed to allow the simple average of the lagged $\Delta v$ to have a coefficient different from 1. These results appear in the second equation of table 1. The fit is somewhat better and equality of the parameter to 1 is rejected. However, the estimate of the moving average parameter $\beta$ is very close to the estimate from the previous equation and is therefore also outside the anticipated range of values. As the following example shows, a simpler ARIMA formulation produces a better fit.

Example 2: Consider an ARIMA $(1,1,1)$ model for $\mathrm{v}_{\mathrm{t}}$, that is, with both $\mathrm{a}(\mathrm{L})=\alpha$ and $\mathrm{b}(\mathrm{L})=\beta$ constant. Then the optimal monetary rule is

$$
\Delta m_{t}^{*}=\Delta x_{t}^{*}-\alpha \Delta v_{t-1}+(1+\beta)\left(x_{t-1}^{*}-x_{t-1}\right)
$$

The empirical support for equation (10) is considerably stronger than that for equation (9). Estimates of the ARIMA $(1,1,1)$ model corresponding to equation (2) are shown in line 3 of table 1 (higher order terms are insignificant for both the autoregressive and the moving average components). The autoregressive component implies a lagged velocity adjustment of .889 times the previous period's change in velocity, plus a reaction to the previous period's

4 McCallum has indicated that a $\lambda$ of this magnitude leads to instability when used in his simulation experiments. We should note that our estimates using monthly data may produce in principle an implicit value of $\lambda$ that differs from that obtained with quarterly data, which is the frequency used by McCallum. Nevertheless, time aggregation of an MA(1) or ARIMA $(1,1,1)$ process from monthly to quarterly data leads to an ARMA structure of the same order (see Harvey (1981, p. 44)), and our estimate of $\beta$ with quarterly data is .191, which is very close to the monthly estimate of .175 . 
gap between actual and target nominal income that corresponds to .292 of the gap. This latter figure is well within the range assumed by McCallum in his simulations, but is used in conjunction with a velocity adjustment based on only one lag.

In order to decide which specification is better, the $\operatorname{ARIMA}(1,1,1)$ model versus the model with the McCallum-type 48-month term, in equation 4 of table 1, we include both the one-lag velocity adjustment corresponding to the $\operatorname{ARIMA}(1,1,1)$ model and the McCallumtype term. Only the one-lag term is significant; the longer moving average adjustment is insignificant with a t-statistic on its coefficient smaller than one. In the fifth equation in the table, the ARIMA $(1,1,1)$ form is estimated over the longer sample period starting with March 1959, since the MA(1) term only requires using up one observation at the beginning while the model with the McCallum average uses up 48 observations. The results are stable in comparison with the same model estimated over shorter periods, as in the third and sixth equations. A test for a break at October 1979 in equation 5 is insignificant, with a p-value of 0.24 .

In the seventh equation of table 1 , the $\operatorname{ARIMA}(1,1,1)$ model is estimated using $\mathrm{M} 2$ in place of the monetary base, with very similar results. The parameter estimates are close to those obtained with the base, and higher order autoregressive and moving average terms are again insignificant. The implication is that the monetary policy rule represented by equation (10) is also feasible with M2 as the instrument and with parameters that are similar to those that are optimal with the base. The M2 velocity equation is also stable, as illustrated by the last equation in the table. A test for a break at October 1979 is also insignificant in this case, with a p-value of 0.43 . 


\section{Multivariate Analysis}

The foregoing results suggest that it may be possible to target nominal income with a monetary aggregate as instrument, making very few structural assumptions. However, the use of such a rule is feasible only if the relationships between money and income assumed above are both strong and stable over time. In this section, we examine these empirical relationships in a multivariate vector autoregression (VAR) context that includes nominal income, inflation and either the monetary base or M2.

The analysis in this section is similar to that of Feldstein and Stock (1994), who focus on what may be interpreted as alternative formulations of the nominal income equation from a series of VARs with different sets of variables. There are two main differences, however. First, we use monthly rather than quarterly data. Although the concept of nominal income is most directly captured by nominal GDP, as used by Feldstein and Stock, our proxy based on the index of coincident indicators and the consumer price index is very similar and allows for the use of the available monthly money series. This difference does not affect the results much, as evidenced by the similarity between the monthly results in the text and the quarterly results provided for reference in the appendix. Testing for the appropriate lag length in our VAR led to the use of nine monthly lags. This is consistent with the FeldsteinStock specification, which uses three quarterly lags.

A second key difference between this and the Feldstein-Stock paper is related to a break in the data that is frequently identified as having occurred in 1979-80. We focus on the period since October 1979 as one in which the performance of the monetary aggregates is poor, rather than on identifying the exact timing of the break, which seems to be a higher 
priority for Feldstein and Stock. A detailed discussion of the timing of the break is also found in Huizinga and Mishkin (1986).

Table 2 contains summary Granger-Sims causality statistics for a VAR containing nominal growth, inflation and growth in the monetary base. Specifically, the table reports the significance probability (p-value) of each of the $F$ tests that corresponds to the joint hypothesis that the coefficients of all the lags of a given variable are equal to zero. The full sample results in the upper panel of the table suggest an orderly pattern in which, at a 5 percent level of significance, the monetary aggregate helps predict both income and inflation, but is itself not predicted by income and inflation. However, this apparent order is called to question by the analysis of subperiods.

The upper panel contains the p-value for a Chow test of a break in October 1979, presents strong evidence that the model is not stable. Furthermore, the results for the postOctober 1979 sample, presented in the lower panel, give a totally different picture of the relationships. In this panel, only a variable's own lags are significant at the 5 percent level. Specifically, the monetary base is very insignificant in both the nominal income and inflation equations. ${ }^{5}$ Although we will look at various refinements of this analysis, these results do not bode well for the use of the monetary base in a policy rule, or even for its use as an information variable. Table 2 (like some subsequent tables) also contains $t$ statistics for the

$s$ These results are consistent with those obtained by Friedman and Kuttner (1992) with quarterly data for the 1970-1990 period. In this paper, however, we examine whether it is possible to improve on the Friedman-Kuttner results by using monthly data, by adding data since 1990, and by including several refinements in the measure of money. We do not include here Friedman and Kuttner's preferred measure, the commercial paper-Treasury bill spread, since it has been shown elsewhere to perform poorly in the 1990s. See, for example, Watson (1991) and Estrella and Mishkin (1995). 
sums of the lag coefficients of the key regressors. In addition to the significance of these sums, the $t$ statistics indicate whether the relationships have the appropriate signs.

Table 3 contains analogous results for a VAR containing M2. The results differ from those of table 2 in several important respects. First, the pattern of the full sample results is different: lags of M2 do not help explain inflation, but lags of both inflation and nominal growth help explain money growth. Second, the evidence of a break in October 1979 is much weaker in the first two equations, especially in the nominal income equation. This is consistent with the Feldstein-Stock results, and it is a point that they emphasize in their reading of the results.

Nevertheless, if we turn to the results in the lower panel for the latter part of the sample, the significance levels of M2 growth are not encouraging in either the nominal income or the inflation equations. In this sense, the post-October 1979 results are very similar to those obtained with the monetary base. One difference encountered here is that lags of inflation are significant in the equation for M2. This could be potentially important if M2 had been used over this period in countercyclical policy to control the variability of inflation because, in that case, successful monetary policy might make it impossible to detect a predictive relationship running from money to inflation. This possibility is explored further in section 7 .

Feldstein and Stock also estimate what amounts practically to the nominal growth equation in our VAR using an error correction specification, which allows for cointegration 
of M2 velocity and short-term interest rates. ${ }^{6}$ We performed a similar exercise by estimating a cointegrating equation with the level of M2 velocity and the 3-month Treasury bill rate and inserting the first lag of the residual from this equation into the nominal growth equation in the VAR. For the full 1959-95 sample, the results were consistent with those of Feldstein and Stock in that the joint significance of the M2 lags and the error correction term was somewhat stronger, with the latter term in itself significant at the 10 percent level (joint p-value of .005 compared with .009 for M2 in table 3 ). In the post-1979 sample, however, the error correction term was not significant and there was no improvement in the joint significance level with its introduction (joint p-value of .547 compared with .456 for M2 in table 3).

\section{Multivariate Analysis with Time Domain Adjustments}

Although the Granger-causality tests above are not very encouraging for the use of monetary aggregates in a policy rule, the analysis in section 3 suggests that forecasts of velocity, explicit or implicit, might be used to help improve the performance of a moneybased policy rule. For instance, the McCallum rule may be interpreted as a way of adjusting for changing trends in velocity in order to target nominal income more accurately. In this section, we adjust the money growth variable that appears in the VARs of the previous section by adding to it some measure of the expected change in velocity. Formally, the variable in the VAR is

6 A seminal discussion of cointegration, error correction, and their relationship with VARs is found in Engle and Granger (1987). 


$$
\Delta m_{t}^{A}=\Delta m_{t}+A_{t}
$$

where, for example,

$$
A_{t}=\frac{1}{48}\left(v_{t-1}-v_{t-49}\right)=\frac{1}{48}\left(\Delta v_{t-1}+\ldots+\Delta v_{t-48}\right)
$$

the McCallum 4-year simple average of changes in velocity. Alternatively,

$$
A_{t}=\frac{1}{48}\left(v_{t-1}-v_{t-49}\right)+\beta \epsilon_{t-1}
$$

the McCallum average adjusted for moving average errors, or

$$
A_{t}=\alpha \Delta v_{t-1}+\beta \epsilon_{t-1}
$$

the change in velocity forecast from the $\operatorname{ARIMA}(1,1,1)$ model.

Table 4 presents the p-values for the adjusted monetary base in the nominal growth and inflation equations from the VAR. The first line repeats results from table 2 for comparison, and the results of the above adjustments are shown in the next three lines. In the nominal growth equation, none of the adjustments do anything to improve the significance of the aggregate; in fact, the p-values are higher. Note, however, that in each case, the Chow test for the break becomes insignificant, so that the adjustments do succeed in producing more stable equations.

The effect of the adjustments on the inflation equation is in a sense the opposite. In each case, there is a reduction in the p-values, although clearly even the lowest figure of .334 (for the 48-month average with a moving average term) is unacceptably high. In this 
case, however, the adjustments fail to make a dent in the stability problem, with very strong signals of a break for all three adjustments.

Comparable results for M2 are found in table 5. As in the case of the monetary base, there is no improvement in the significance of M2 in the nominal income equation with any of the adjustments. In the inflation equation, two of the three adjustments improve significance, but not nearly enough to make the levels acceptable.

Thus, the McCallum insight of adjusting for predictable components in the change in velocity produces some empirical gains, especially in the inflation equation, but these gains are too marginal to make the relationships useful in practice. This conclusion holds even with the weak requirements associated with the use of the aggregates as information variables, and even more strongly in the context of their employment in formal policy rules.

\section{Multivariate Analysis with Frequency Domain Adjustments}

An alternative way to adjust monetary aggregates to improve their performance in explaining income and inflation is to remove components in the frequency domain that might be obscuring the relationship between the monetary aggregates and nominal income and inflation. An informal justification for the long (4-year) moving average of changes in velocity in the McCallum policy rule is that it would tend to capture persistent changes in the velocity process without placing too much emphasis on short-term fluctuations. McCallum (1988, footnote 13) states that 
As the purpose of this term is to take account of possible changes in velocity growth resulting from regulatory and technological sources, the period of averaging should be long enough to avoid dependence on cyclical conditions (which are reflected in the third term).

Here "the third term" refers to the previous period's gap between target and actual nominal income, as in equation (9).

As shown in section 3, this interpretation is not entirely consistent with the optimization framework presented there, since the empirical estimates suggest a simpler form with only one lag. Nevertheless, we show in this section that McCallum's reasoning does have some empirical support. If the velocity series is decomposed by spectral methods into various frequency bands, the evidence suggests that only the low frequency band exhibits instability across the October 1979 break point.

Thus, as before, define the change in velocity by

$$
\Delta v_{t}=\Delta x_{t}-\Delta m_{t}
$$

To construct the frequency band decomposition, we computed the Fourier transform of the demeaned $\Delta v_{t}$ series using data from February 1959 to December $1995 .^{7}$ The decomposition

7 We used the Fourier and inverse Fourier transforms in the RATS econometrics package with the algorithm provided for choosing the number of frequency points in the frequency domain. No smoothing was applied. 
was accomplished by retaining only the points in each of three frequency bands and applying the inverse Fourier transform. ${ }^{8}$ The frequency bands are:

Low frequencies: cycles longer than eight years,

Medium frequencies: cycles longer than one year and no longer than eight

(corresponding to the business cycle), ${ }^{9}$ and

High frequencies: cycles up to one year.

The stability test applied to these components is very simple: each one is regressed on a constant term and a dummy that is 1 starting with October 1979 and 0 otherwise. The results are shown in table 6 . It is fairly clear that the velocity of the monetary base is lower in the second part of the sample. When the frequency band components are examined, only the low frequencies exhibit instability, much more strongly so than the aggregate series.

The results are similar for $\mathrm{M} 2$ velocity, although the change in trend is positive and not as noticeable in the aggregate series, for which the break has a level of significance of 22 percent. However, once the frequency decomposition is applied, it is clear that there is a break and that it is exclusively concentrated in the low frequency component, as was the case for the velocity of the monetary base. Figure 1 plots the low frequency components of both base and M2 velocities over the sample period. The trends found in table 6 are readily

${ }^{8}$ For a thorough discussion of Fourier transforms and spectral analysis in general, see Brillinger (1981).

9 The recent literature typically adopts frequencies of 18 months or two years as the lower bound for the business cycle. We find, however, that such representations do not coincide with the NBER turning points, particularly with regard to the two separate recessions in 1980-82. Our convention fits the NBER dates more closely and corresponds to that of Granger and Hatanaka (1964). 
apparent in the figure, although it is also clear that these low frequency fluctuations are more complicated than a simple step function.

This evidence of instability in the low frequency components of the base and M2 velocities suggests that the higher frequency relationships between money and nominal income may be stronger and more stable that those of the aggregate series. This point is examined in the last row of tables 4 and 5 , which report the results of performing the VAR exercise of the previous section on only the medium and high frequency components of nominal income, inflation and money growth. ${ }^{10}$ This is equivalent to running a bandspectrum VAR in the sense of the band-spectrum regressions proposed by Engle (1974).

Although there is a noticeable improvement in the significance level of the monetary variables in the band-spectrum equations, it is still insufficient to achieve standard levels of acceptability. In each case, the significance level is lower than in any of the other equations, either unadjusted or with time-domain adjustments. Nevertheless, the best performance is in the inflation equation with the monetary base, where the significance level is 28.5 percent. Another unattractive feature of the spectral VARs is that for both the base and M2, the inflation equation has a break in October 1979. Of course, with the low significance levels, this is of secondary importance.

10 We also estimated the VAR with either the high or the medium frequency component (rather than the low frequency component) excluded from all three variables. In both cases, the significance of the key parameter estimates was reduced considerably. Thus, the only frequency domain adjustment that seems promising is the exclusion of the low frequencies, as reported in the text. 


\section{Interest Rates as Benchmarks: Do They Outperform the Aggregates?}

In the literature, a standard follow-up to empirical findings against the usefulness of monetary aggregates is to perform similar tests with interest rates, which are sometimes found to be more informative for monetary policy purposes. In this paper, we follow that time-honored tradition, although the results are not necessarily the standard ones. We specifically run a VAR with income growth, inflation and the first-differenced federal funds rate, the latter in place of the money growth measures of sections 4 to 6 . Since earlier research, for instance Feldstein and Stock (1994), has found a significant relationship between interest rates and real income, but not nominal income, we run the interest rate equations with both real and nominal income. The estimation period is from October 1979 to December 1995, corresponding to the period we emphasized in the context of the monetary aggregates.

The significance level ( $p$-value) of the 9 lags of the change in the funds rate is .706 for nominal income, .628 for real income, and .091 for inflation. ${ }^{11}$ The results for nominal income and inflation are consistent with the conventional wisdom about these relationships. The relationship between the funds rate and nominal income is weak, while in the case of inflation, the sum of the coefficients of the funds rate is unexpectedly positive and has a pvalue of 0.059 . The insignificance in the real income equation is somewhat puzzling, however, in light of previous findings. ${ }^{12}$ Two explanations come to mind for this.

11 The results of the price equation are the same in both VARs with real or nominal income because of the linear dependence of the explanatory variables.

12 For example, Feldstein and Stock (1994) and Hess, Small and Brayton (1993). 
First, a strong relationship between interest and income is frequently found in small models that do not control for other factors, including lagged values of the relevant series. In the richer VAR context, the marginal significance of the interest rate variable may be low and there is little we would be able to do in that case. A second more interesting explanation is that, if the interest rate is used successfully by policymakers to smooth the target variable (income growth or inflation), it may be impossible to detect significance (Granger-Sims causality) going from the interest rate to the target variable. If this were the case, however, it should be possible to detect significance going the other way, since deviations from trend in the target variable would provoke changes in the interest rate in a specific direction.

Thus, if the funds rate is used to smooth income growth, one would expect that the rate would rise in response to faster growth or decline in response to slow or negative growth, leading to a positive relationship. In fact, this type of logic can also be applied to the monetary aggregates. The insignificance of the aggregates, adjusted or unadjusted, in the nominal income growth and inflation equations since October 1979 might be attributable to their use in smoothing fluctuations in those variables. In this case, faster growth in the target variable would prompt a slowing down of money growth, leading to a negative relationship. ${ }^{13}$

13 Note however that the expected signs of these relationships may depend on whether policymakers are reacting to demand shocks or to supply shocks. The presence of supply shocks in the sample could make it more difficult to observe the signs we postulate in the text. A more careful analysis of these possibilities could proceed by formulating and estimating a policy reaction function, which is beyond the scope of this paper. Some analysis of a policy reaction function may be found in Taylor (1993) for the United States and in Clarida and Gertler (1996) for Germany. 
Table 7 investigates this phenomenon. For any VAR equation described in sections 4 to 7, estimated from October 1979 to December 1995, in which a target variable is significant in the money or interest rate equation, the table shows the sum of the coefficients of the lags of the target variable and the level of significance of the sum. For example, the first line shows the significance of lags of nominal income growth in the equation for the monetary base, the latter adjusted by McCallum's 4-year velocity adjustment with a moving average term. The lags of income growth are significant at the .007 level and the sum of the lag coefficients is negative (-.098), as suggested by the above discussion. However, the negative sum is not significant, and the support for the explanation is not compelling.

For most of the equations corresponding to monetary aggregates, the coefficients have a positive sum, contradicting the proposed explanation. In fact, these positive sums are in some cases significant, lending very little credence to the story. As was the case in the earlier analysis, the strongest case is provided by M2 with the frequency domain adjustment. As the penultimate line of the table shows, the coefficient sum is -.292 in that case, although the level of significance is still too high at .160 to be convincing.

The results for the federal funds rate, while not unanimous, are much more supportive of the story. For both nominal and real income, the results indicate that the sum of lag coefficients is significantly positive, as expected, at the .001 level. This suggests that the funds rate may have been used to smooth real or nominal income fluctuations over the estimation period. For inflation in the funds rate equation, the results are puzzling, since they are negative and significant at the .05 level. 
To summarize, interest rates do not provide a benchmark that is clearly superior to the monetary aggregates in the context of our analysis. The significance of empirical relationships running from interest rates to income growth and inflation is not strong. Nevertheless, there is evidence that the weak empirical results could be due to the use of the funds rate for smoothing income fluctuations. The same cannot be said of the monetary aggregates.

\section{Some Evidence from Germany: Output, Prices and M3}

Even though there are in the United States some notable proponents of the use of monetary aggregates in monetary policy, there are many more who would argue that the U.S. evidence in this regard is far from compelling. It is useful, therefore, to perform some of the analysis of the foregoing sections with German data, since German economists and policymakers are more likely to be strong advocates of the monetary aggregates than their U.S. counterparts. In this section, we apply the principal tests of sections 4 through 7 to data for western Germany: nominal GDP growth, growth in the GDP deflator, the broad M3 aggregate (on which the Bundesbank focuses), ${ }^{14}$ and the rate of interest controlled by the monetary authority. For the latter, no series is available continuously for the entire period, and we use the Lombard rate until the first quarter of 1982, and the overnight repo rate from then onwards.

14 Data for GDP, the GDP deflator and M3 were obtained from the Bundesbank. GDP and the deflator are for western Germany only, even in the post-reunification period. 
VAR results analogous to those presented for the United States in table 3 appear in table 8. The results are in fact very consistent with those obtained with U.S. M2. For example, there is evidence that M3 is a strong predictor of nominal and real growth over the full sample, but not of inflation. In the German case, the joint test of the lags of $M 3$ in the nominal growth equation for the full sample is not obviously conclusive with a p-value of .074. However, the sum of those coefficients is significant at the $1 \%$ level. Moreover, if the post-reunification period is excluded, recognizing the difficulty in making these data fully consistent with the past, the results are very strong. Both the joint test and the test of the sum are significant at the $1 \%$ level.

Also consistent with the U.S. results are the consequences of focusing on data since October of 1979. For Germany, this is not as clear a break point as it is for the United States. Nevertheless, the 1980 s and 1990 s are associated with financial innovations that may have changed the traditional relationships among economic variables. Table 9 shows the German results for this latter period, both including and excluding the post-reunification period. There are essentially no significant results in either panel of table 9.

Other than the own lags of M3 in the top panel, the only result that is significant at the $5 \%$ level is that for the sum of the lags of inflation in the money equation, also in the top panel. As discussed in section 7 , the significance of this sum might be an indication that $M 3$ was set in reaction to current observed inflation, a procedure which, if successful, could obscure the observed effects of M3 on inflation. This interpretation is not supported, however, since the positive sign would imply that M3 would grow faster in reaction to higher inflation. 
When interpreting the results of table 9 , it should be noted that the post-1979 and prereunification sample is not very large, which could certainly affect significance. The problem is worse in Germany than in the United States because of the possible differences in the post-reunification data.

Tables 10-12 examine the performance of the central bank interest rate in predicting growth and inflation, both by itself and in conjunction with M3. Table 10 shows that the central bank rate is not significant for either growth or inflation but that, like in the United States, the rate may be reacting to fast economic growth. This result is also seen in table 11, which adds also M3 to the VAR, but not in table 12, which excludes the post-reunification data. Table 12 does show that the predictive power of $\mathrm{M} 3$ for nominal and real growth in the 1970-1990 period remains even with the inclusion of the interest rate variable in the VAR.

To summarize, the results of the multivariate analysis in Germany are very similar to those obtained for the United States. For the full sample period, there is evidence in both countries that monetary aggregates are predictors of subsequent economic growth. However, for the period since October 1979, there are no clear signs that M3 is useful as an information variable. While it is possible that the estimation of a more detailed structural model could extract more information than our straightforward predictive analysis, it seems unlikely that strong relationships can be ascertained for the latter period. ${ }^{\text {is }}$

is Clarida and Gertler (1996) have found evidence that the German repo rate reacts to deviations of both real growth and inflation from target levels. This pattern, similar to Taylor's (1993) rule, is somewhat consistent with the results in our tables 10 and 11. Also, Bernanke and Mihov (1996) have found evidence that expected German M3 influences the Lombard rate. Their results are not directly comparable to those of this paper, since they 


\section{Conclusion}

At the outset, we identified three possible roles for monetary aggregates in monetary policy: as information variables, as indicators of policy actions and as instruments in a policy rule. These roles require successively stronger and stable relationships between the aggregates and the final policy targets. Our empirical results show that in the United States since 1979 , the monetary aggregates fall considerably short of those requirements. We have tried to present the aggregates in the best possible light by employing sensible adjustments suggested in the literature and by developing further adjustments to increase their precision. Some of the new adjustments proved more successful than the earlier suggestions, but not enough to make a compelling case.

We have also compared the aggregates to interest rates and investigated the possibility that empirical relationships may not be reflective of causal relationships because of the use of these variables in countercyclical policy. The results were supportive of this notion in the case of interest rates, but not in the case of the monetary aggregates.

The results with German M3 were hardly more favorable for the use of M3 as an information variable. In fact, the German results are very consistent with those for the United States, particularly with U.S. M2, and do not exhibit any obvious significance in the period since 1979.

Although our results have not ruled out that monetary aggregates cannot be used in some complicated way as an information variable, they do indicate that the monetary

test whether money is a target for the Bundesbank, not whether it influences or is influenced by output or inflation. 
aggregates, the monetary base and M2 in particular, currently cannot be used in a straightforward way for monetary policy purposes. Whatever their informational content may have been in earlier time periods, they do not seem to provide adequate and consistent information at present in the United States. The inability of monetary aggregates to perform well as straightforward information variables in recent periods has the implication that they cannot be used to signal the stance of monetary policy, an important requirement if money growth targets are to be used as part of a strategy to increase the transparency of monetary policy to the public and the markets.

We should note, however, that the majority of the period we focus on has been one of relative price stability in the United States and Germany. The problem with monetary aggregates as a guide to monetary policy is that there frequently are shifts in velocity that alter the relationship between money growth and nominal income. A way of describing this situation is to think of velocity shocks as the noise that obscures the signal from monetary aggregates. In a regime in which changes in nominal income, inflation and the money supply are subdued, the signal-to-noise ratio is likely to be low, making monetary aggregates a poor guide for policy. However, in other economies or in other time periods in which we experience more pronounced changes in money and inflation, the velocity shocks might become small relative to the swings in money growth, thus producing a higher signal-to-noise ratio. In these situations, the results could very well be different and monetary aggregates could usefully play a role in the conduct of monetary policy. 


\section{References}

Bernanke, Ben S. and Ilian Mihov, "What Does the Bundesbank Target?", International Seminar on Macroeconomics, NBER and Institute for Advanced Studies, June 1996.

Brillinger, David R., Time Series: Data Analysis and Theory, Holden Day, 1981.

Clarida, Richard and Mark Gertler, "How the Bundesbank Conducts Monetary Policy", New York University Working Paper RR \# 96-14, April 1996.

Engle, Robert F., "Band Spectrum Regression", International Economic Review, February $1974,1-11$.

Engle, Robert F. and C.W.J. Granger, "Cointegration and Error Correction: Representation, Estimation, and Testing", Econometrica, March 1987, 251-276.

Estrella, Arturo and Frederic S. Mishkin, "Predicting U.S. Recessions: Financial Variables as Leading Indicators", NBER Working Paper No. 5379, December 1995.

Feldstein, Martin and James H. Stock, "The Use of Monetary Aggregate to Target Nominal GDP", in N. Gregory Mankiw, ed., Monetary Policy, University of Chicago, 1994. 
Friedman, Benjamin M. and Kenneth N. Kuttner, "Money, Income, Prices, and Interest Rates", American Economic Review, June 1992.

Friedman, Milton, "The Effects of a Full-Employment Policy on Economic Stability: A Formal Analysis", in Essays in Positive Economics, University of Chicago, 1953.

Friedman, Milton, "The Role of Monetary Policy", American Economic Review, March 1968.

Granger, C.W.J. and M. Hatanaka, Spectral Analysis of Economic Time Series, Princeton, 1964.

Harvey, A.C., Time Series Models, Philip Allan, 1981.

Hess, Gregory D., David H. Small and Flint Brayton, "Nominal Income Targeting with the Monetary Base as Instrument: An Evaluation of McCallum's Rule", Federal Reserve Board Finance and Economic Discussion Series, March 1993.

Huizinga, John and Frederic S. Mishkin, "Monetary Policy Regime Shifts and the Unusual Behavior of Real Interest Rates", Carnegie-Rochester Conference Series on Public Policy, Spring 1986, 231-274. 
Judd, John P. and Brian Motley, "Nominal Feedback Rules for Monetary Policy", Federal Reserve Bank of San Francisco Economic Review, Summer 1991.

Lucas, Robert E., Jr., "Econometric Policy Evaluation: A Critique", Carnegie-Rochester Conference Series on Public Policy, 1976, 19-46.

McCallum, Bennett T., "Robustness Properties of a Rule for Monetary Policy", CarnegieRochester Conference Series on Public Policy, 1988, 173-204.

McCallum, Bennett T., "Concluding Observations", in Marvin Goodfriend and David H. Small, eds., Operating Procedures and the Conduct of Monetary Policy: Conference Proceedings, Federal Reserve Board, March 1993a.

McCallum, Bennett T., "Specification and Analysis of a Monetary Policy Rule for Japan", Bank of Japan Monetary and Economic Studies, November 1993b, 1-45.

McCallum, Bennett T., "Comment" on Feldstein, Martin and James H. Stock, "The Use of Monetary Aggregate to Target Nominal GDP", in N. Gregory Mankiw, ed., Monetary Policy, University of Chicago, 1994.

Sims, Christopher A., "Are Forecasting Models Usable for Policy Analysis?", Federal Reserve Bank of Minneapolis Quarterly Review, Winter 1986. 
Taylor, John B., "Discretion Versus Policy Rules in Practice", Carnegie-Rochester

Conference Series on Public Policy, December 1993, 195-214.

Watson, Mark, "Using Econometric Models to Predict Recessions", Federal Reserve Bank of

Chicago Economic Perspectives, 15:6, November/December 1991. 
Table 1

Univariate ARIMA Models of Velocity

For the Monetary Base and M2 (Monthly)

\begin{tabular}{|c|c|c|c|c|c|c|c|}
\hline & Monetary & Estimation & \multicolumn{3}{|c|}{ Coefficient Estimates (Standard Error) } & \multirow{2}{*}{$\begin{array}{l}\text { Standard } \\
\text { Error (Equ.) }\end{array}$} & \multirow[b]{2}{*}{$\underline{\mathrm{R}^{2}}$} \\
\hline Equation & Aggregate & Period & $\underline{\operatorname{AR} 1(\alpha)}$ & $\operatorname{MA1}(\beta)$ & McCallum $(\gamma)$ & & \\
\hline 1 & Base & Mar 63- Dec 95 & 0 & $\begin{array}{c}.175 \\
(.050)\end{array}$ & 1 & .00509 & .076 \\
\hline 2 & Base & Mar 63- Dec 95 & 0 & $\begin{array}{c}.173 \\
(.050)\end{array}$ & $\begin{array}{c}.629 \\
(.162)\end{array}$ & .00506 & .089 \\
\hline 3 & Base & Mar 63- Dec 95 & $\begin{array}{c}.889 \\
(.046)\end{array}$ & $\begin{array}{l}-.708 \\
(.071)\end{array}$ & 0 & .00494 & .133 \\
\hline 4 & Base & Mar 63- Dec 95 & $\begin{array}{c}.846 \\
(.073)\end{array}$ & $\begin{array}{l}-.662 \\
(.097)\end{array}$ & $\begin{array}{c}.062 \\
(.067)\end{array}$ & .00494 & .135 \\
\hline 5 & Base & Mar 59- Dec 95 & $\begin{array}{c}.846 \\
(.056)\end{array}$ & $\begin{array}{l}-.647 \\
(.081)\end{array}$ & 0 & .00502 & .127 \\
\hline 6 & Base & Oct $79-$ Dec 95 & $\begin{array}{c}.871 \\
(.064)\end{array}$ & $\begin{array}{l}-.613 \\
(.103)\end{array}$ & 0 & .00487 & .168 \\
\hline 7 & M2 & Mar 59- Dec 95 & $\begin{array}{c}.753 \\
(.062)\end{array}$ & $\begin{array}{l}-.403 \\
(.086)\end{array}$ & 0 & .00514 & .221 \\
\hline 8 & M2 & Oct 79- Dec 95 & $\begin{array}{c}.736 \\
(.092)\end{array}$ & $\begin{array}{l}-.342 \\
(.128)\end{array}$ & 0 & .00519 & .250 \\
\hline
\end{tabular}

Equation is of the form:

$$
\Delta v_{t}=\alpha \Delta v_{t-1}+\epsilon_{t}+\beta \epsilon_{t-1}+\gamma \overline{\Delta v}_{t-1}
$$

where $\Delta v_{t}=\Delta \log (C O I N)+\Delta \log (C P I)-\Delta \log (M)$

COIN $=$ Commerce Department $/$ Conference Board index of coincident indicators

$\mathrm{CPI}=$ Consumer price index

$\mathrm{M}=$ Monetary base or M2

$\overline{\Delta v}_{t}=1 / 48\left(v_{t}-v_{t-48}\right)$ 
Table 2

Joint Significance Tests in VAR with Nominal Growth, Inflation and Monetary Base

(Monthly, 9 lags)

\begin{tabular}{|c|c|c|c|c|c|c|c|}
\hline riod & $\begin{array}{l}\text { Dependent } \\
\text { Variable }\end{array}$ & $\begin{array}{l}\text { p-values for: } \\
\text { Nominal Growth }\end{array}$ & Inflation & Money & $\underline{\mathrm{R}^{2}}$ & $\begin{array}{l}\text { p-values for: } \\
\text { Break (Oct 79) }\end{array}$ & $\begin{array}{l}\text { Coeff. } \\
\text { Sum on }\end{array}$ \\
\hline
\end{tabular}

\begin{tabular}{|c|c|c|c|c|c|c|c|c|c|}
\hline \multirow[t]{3}{*}{ Mar 60- Dec 95} & Nominal Growth & .000 & .002 & .021 & .289 & .019 & Money & 2.70 & .007 \\
\hline & Inflation & .001 & .000 & .001 & .608 & .006 & Money & 1.44 & .150 \\
\hline & Money & .162 & .384 & .000 & .366 & .020 & $\begin{array}{l}\text { Growth } \\
\text { Inflation }\end{array}$ & $\begin{array}{r}-0.10 \\
0.49\end{array}$ & $\begin{array}{l}.918 \\
.627\end{array}$ \\
\hline \multirow[t]{3}{*}{ Oct 79- Dec 95} & Nominal Growth & .000 & .078 & .673 & .310 & & Money & 1.68 & .096 \\
\hline & Inflation & .092 & .000 & .384 & .631 & & Money & 0.34 & .731 \\
\hline & Money & .693 & .852 & .000 & .353 & & $\begin{array}{l}\text { Growth } \\
\text { Inflation }\end{array}$ & $\begin{array}{r}-1.58 \\
0.10\end{array}$ & $\begin{array}{l}.115 \\
.919\end{array}$ \\
\hline
\end{tabular}

Nominal Growth $=\Delta \log (\mathrm{COIN})+\Delta \log (\mathrm{CPI})=\Delta \mathbf{x}_{\mathbf{t}}$

Inflation $=\Delta \log (\mathrm{CPI})=\Delta \mathrm{p}_{\mathrm{t}}$

Money $=\Delta \log ($ BASE $)=\Delta \mathrm{m}_{1}$ 
Table 3

Joint Significance Tests in VAR with

Nominal Growth, Inflation and M2

(Monthly, 9 lags)

\begin{tabular}{|c|c|c|c|c|c|c|c|c|}
\hline Period & $\begin{array}{l}\text { Dependent } \\
\text { Variable }\end{array}$ & $\begin{array}{l}\text { p-values for: } \\
\text { Nominal Growth }\end{array}$ & Inflation & Money & $\underline{\mathrm{R}^{2}}$ & $\begin{array}{l}\text { p-values for: } \\
\text { Break (Oct 79) }\end{array}$ & $\begin{array}{l}\text { Coeff. } \\
\text { Sum on }\end{array}$ & t Statistic $\mathrm{p}$-value \\
\hline
\end{tabular}

\begin{tabular}{|c|c|c|c|c|c|c|c|c|c|}
\hline \multirow[t]{3}{*}{ Mar 60- Dec 95} & Nominal Growth & .000 & .036 & .009 & .293 & .449 & Money & 3.74 & .000 \\
\hline & Inflation & .002 & .000 & .484 & .590 & .080 & Money & 0.03 & .977 \\
\hline & Money & .004 & .007 & .000 & .625 & .036 & $\begin{array}{l}\text { Growth } \\
\text { Inflation }\end{array}$ & $\begin{array}{r}-1.87 \\
1.50\end{array}$ & $\begin{array}{l}.063 \\
.134\end{array}$ \\
\hline \multirow[t]{3}{*}{ Oct 79- Dec 95} & Nominal Growth & .000 & .130 & .456 & .319 & & Money & 1.55 & .122 \\
\hline & Inflation & .253 & .000 & .482 & .628 & & Money & 0.71 & .477 \\
\hline & Money & .122 & .014 & .000 & .643 & & $\begin{array}{l}\text { Growth } \\
\text { Inflation }\end{array}$ & $\begin{array}{r}-0.45 \\
0.35\end{array}$ & $\begin{array}{l}.656 \\
.730\end{array}$ \\
\hline
\end{tabular}

Nominal Growth $=\Delta \log (\mathrm{COIN})+\Delta \log (\mathrm{CPI})=\Delta \mathrm{x}_{\mathrm{t}}$

Inflation $=\Delta \log (\mathrm{CPI})=\Delta \mathrm{p}_{\mathrm{t}}$

Money $=\Delta \log (\mathrm{M} 2)=\Delta \mathrm{m}_{\mathrm{l}}$ 
Table 4

Significance and Stability (p-values) of Adjusted Monetary Base

In Nominal Growth and Inflation Equations

(Monthly, 9 lags, Oct 79 to Dec 95)

Adjustment

to Base

None

48-mo. average

48-mo. average

with MA term

$\operatorname{ARIMA}(1,1,1)$

Low frequencies excluded
Equation

\begin{tabular}{|c|c|c|c|}
\hline \multicolumn{2}{|c|}{ Nominal Growth } & \multicolumn{2}{|l|}{ Inflation } \\
\hline Significance & Break* & Significance & Break* \\
\hline .673 & .019 & .384 & .006 \\
\hline .796 & .105 & .351 & .006 \\
\hline .792 & .160 & .334 & .004 \\
\hline .772 & .127 & .373 & .002 \\
\hline .460 & .265 & .285 & .003 \\
\hline
\end{tabular}

Adjusted Base $=\Delta m^{\wedge} \mathfrak{t}=\Delta m_{\mathfrak{t}}+A_{\mathfrak{t}}$ where

$$
\begin{aligned}
A_{t} & =1 / 48\left(v_{t-1}-v_{t-19}\right) \quad(48-m o . \text { average }) \\
& =1 / 48\left(v_{t-1}-v_{t-49}\right)+1.171 \epsilon_{t-1}(48-m o . \text { average with MA term) } \\
& \left.=.846 \Delta v_{t-1}+.353 \epsilon_{t-1} \quad \text { (ARIMA }(1,1,1)\right) \\
& =\text { components of VAR variables with cycles }>8 \text { years excluded (low frequencies excluded) }
\end{aligned}
$$

*Break in Oct 79 when estimated from Feb 59 to Dec 95 
Table 5

Significance and Stability (p-values) of Adjusted M2

In Nominal Growth and Price Equations

(Monthly, 9 lags, Oct 79 to Dec 95)

Equation

Adjustment

to M2

None

48-mo. average

48-mo. average

with MA term

$\operatorname{ARIMA}(1,1,1)$

Low frequencies excluded

\begin{tabular}{llll}
\hline Nominal Growth & & Inflation & \\
Significance & Break* & Significance & Break*
\end{tabular}

.456

.449

.482

.080

.562

.589

.532

.255

.503

.635

.432

.290

.546

.444

.366

.131

.294

Adjusted $\mathrm{M} 2=\Delta \mathrm{m}_{\mathrm{t}}^{\mathrm{A}}=\Delta \mathrm{m}_{\mathrm{t}}+\mathrm{A}_{\mathrm{t}}$ where

$A_{t}=1 / 48\left(v_{t-1}-v_{t-49}\right) \quad$ (48-mo average)

$=1 / 48\left(v_{t-1}-v_{t-49}\right)+1.304 \epsilon_{t-1}$ (48-mo. average with MA term)

$=.753 \Delta v_{t-1}+.597 \epsilon_{t-1} \quad(\operatorname{ARIMA}(1,1,1))$

$=$ components of VAR variables with cycles $>8$ years are excluded (low frequencies

excluded)

*Break in Oct 79 when estimated from Feb 59 to Dec 95 
Table 6

Structural Break in Velocity: Analysis by Frequency Bands Monthly Data, Feb 59 to Dec 95

$\begin{array}{llcc}\text { Velocity of } & \text { Frequencies* } & \begin{array}{l}\text { t Statistic } \\ \text { For Break } \\ \text { In Oct 79 }\end{array} & \begin{array}{c}\text { Significance } \\ \text { (t prob) }\end{array} \\ \text { Base } & \text { All } & -5.51 & .000 \\ \text { Base } & \text { Low } & -23.5 & .000 \\ \text { Base } & \text { Medium } & 0.12 & .907 \\ \text { Base } & \text { High } & 0.01 & .993 \\ \text { M2 } & \text { All } & & .223 \\ \text { M2 } & \text { Low } & 1.22 & .000 \\ \text { M2 } & \text { Medium } & 4.38 & .956 \\ \text { M2 } & \text { High } & -0.06 & .943\end{array}$

Velocity $=\Delta \mathrm{v}_{\mathrm{t}}=\Delta \mathrm{x}_{\mathrm{t}}-\Delta \mathrm{m}_{\mathrm{t}}$ $\Delta \mathrm{x}_{\mathrm{t}}=$ nominal growth $=\Delta \log (\mathrm{COIN})+\Delta \log (\mathrm{CPI})$ $\Delta \mathrm{m}_{\mathrm{t}}=$ growth in Base or M2

*Variables are decomposed by computing the inverse Fourier transform of 3 spectral frequency bands: low (cycles longer than 8 years), medium (between 1 and 8 years, corresponding to business cycle), and high (up to one year). 
Table 7

Significance ( $p$-values) of Target Variables In Money and Interest Rate Equations (Monthly, 9 lags, Oct 79 to Dec 95)
Dependent

Variable

Base

Base

M2

M2

Fed Funds** None

Fed Funds None

M2

M2

M2

M2

M2

Fed Funds

None
Adjustment*

48-mo. average with MA term

$\operatorname{ARIMA}(1,1,1) \quad$ Nominal Income

48-mo. average with MA term

$\operatorname{ARIMA}(1,1,1)$

Nominal Income

Nominal Income

Real Income

Inflation

Inflation

Inflation

48-mo. average

with MA term

$\operatorname{ARIMA}(1,1,1) \quad$ Inflation

Inflation

Low Frequer
Excluded

Inflation
Joint

Significance Sum of

Of Lags

.007

Lags

$-.098$

.293

.036

.338

.005

.001

.000

128.

128.

.001

.730

.014

.036

.174

.164

.008

.167

.023

$-.022$

.841

.020

$-.292$

.160

.050

$-60.7$

.046

*Adjustments are described in tables 4 and 5 .

**The federal funds rate enters throughout in first differences. 
Table 8

Joint Significance Tests in VAR for Germany Income Growth, Inflation and M3

(Quarterly, 3 lags)

\begin{tabular}{|c|c|c|c|c|c|c|c|c|}
\hline Period & $\begin{array}{l}\text { Dependent } \\
\text { Variable }\end{array}$ & $\begin{array}{l}\text { p-values for: } \\
\text { Income Growth }\end{array}$ & $\underline{\text { Inflation }}$ & Money & $\underline{\mathrm{R}^{2}}$ & $\begin{array}{l}\text { Coeff. } \\
\text { Sum on }\end{array}$ & $\underline{\text { t Statistic }}$ & p-value \\
\hline \multirow[t]{4}{*}{ Mar 70- Dec 95} & Nominal Growth & .178 & .367 & .074 & .132 & Money & 2.65 & .009 \\
\hline & Inflation & .043 & .247 & .096 & .253 & Money & 0.87 & .389 \\
\hline & Money & .749 & .444 & .000 & .340 & $\begin{array}{l}\text { Growth } \\
\text { Inflation }\end{array}$ & $\begin{array}{r}-0.43 \\
1.35\end{array}$ & $\begin{array}{l}.668 \\
.180\end{array}$ \\
\hline & Real Growth & .315 & .058 & .046 & .135 & Money & 2.34 & .022 \\
\hline \multirow[t]{4}{*}{ Mar 70- Sep 90} & Nominal Growth & .200 & .305 & .008 & .195 & Money & 3.59 & .001 \\
\hline & Inflation & .179 & .263 & .129 & .266 & Money & 0.89 & .379 \\
\hline & Money & .880 & .658 & .001 & .342 & $\begin{array}{l}\text { Growth } \\
\text { Inflation }\end{array}$ & $\begin{array}{r}-0.42 \\
0.75\end{array}$ & $\begin{array}{l}.677 \\
.458\end{array}$ \\
\hline & Real Growth & .071 & .011 & .013 & .206 & Money & 3.21 & .002 \\
\hline
\end{tabular}

Nominal Growth $=\Delta \log \left(\right.$ nominal GDP) $=\Delta x_{1}$ Inflation $=\Delta \log ($ GDP deflator $)=\Delta \mathrm{p}_{\mathrm{t}}$

Money $=\Delta \log \left(\right.$ M3) $=\Delta m_{t}$ 
Table 9

Joint Significance Tests in VAR for Germany Income Growth, Inflation and M3

(Quarterly, 3 lags)

\begin{tabular}{|c|c|c|c|c|c|c|c|c|}
\hline$\underline{\text { Period }}$ & $\begin{array}{l}\text { Dependent } \\
\text { Variable }\end{array}$ & $\begin{array}{l}\text { p-values for: } \\
\text { Income Growth }\end{array}$ & $\underline{\text { Inflation }}$ & Money & $\underline{\mathbf{R}^{2}}$ & $\begin{array}{l}\text { Coeff. } \\
\text { Sum on }\end{array}$ & I Statistic & p-value \\
\hline \multirow[t]{4}{*}{ Dec 79- Dec 95} & Nominal Growth & .551 & .433 & .667 & .108 & Money & 0.20 & .840 \\
\hline & Inflation & .741 & .156 & .335 & .168 & Money & -0.65 & .517 \\
\hline & Money & .378 & .160 & .001 & .390 & $\begin{array}{l}\text { Growth } \\
\text { Inflation }\end{array}$ & $\begin{array}{r}-1.51 \\
2.02\end{array}$ & $\begin{array}{l}.137 \\
.048\end{array}$ \\
\hline & Real Growth & .634 & .097 & .197 & .207 & Money & 0.51 & .613 \\
\hline \multirow[t]{4}{*}{ Dec 79-Sep 90} & Nominal Growth & .453 & .716 & .749 & .130 & Money & -0.55 & .587 \\
\hline & Inflation & .809 & .174 & .201 & .240 & Money & -0.45 & .653 \\
\hline & Money & .682 & .130 & .867 & .245 & $\begin{array}{l}\text { Growth } \\
\text { Inflation }\end{array}$ & $\begin{array}{r}-1.13 \\
1.13\end{array}$ & $\begin{array}{l}.265 \\
.267\end{array}$ \\
\hline & Real Growth & .443 & .091 & .288 & .243 & Money & -0.43 & .669 \\
\hline
\end{tabular}

Nominal Growth $=\Delta \log \left(\right.$ nominal GDP) $=\Delta x_{t}$

Inflation $=\Delta \log ($ GDP deflator $)=\Delta \mathrm{p}_{\mathrm{s}}$

Money $=\Delta \log (\mathrm{M} 3)=\Delta \mathrm{m}_{1}$ 
Table 10

Joint Significance Tests in VAR for Germany Income Growth, Inflation and the Central Bank Rate (Quarterly, 3 lags)

\begin{tabular}{|c|c|c|c|c|c|c|c|c|}
\hline Period & $\begin{array}{l}\text { Dependent } \\
\text { Variable }\end{array}$ & $\begin{array}{l}\text { p-values for: } \\
\text { Income Growth }\end{array}$ & Inflation & Interest Rate & $\underline{\mathbf{R}^{2}}$ & $\begin{array}{l}\text { Coeff. } \\
\text { Sum on }\end{array}$ & $\underline{\text { t Statistic }}$ & p-value \\
\hline \multirow[t]{4}{*}{ Mar 70- Dec 95} & Nominal Growth & .127 & .900 & .193 & .110 & Interest & -0.91 & .368 \\
\hline & Inflation & .041 & .307 & .879 & .204 & Interest & 0.32 & .747 \\
\hline & Interest Rate & .004 & .024 & .000 & .567 & $\begin{array}{l}\text { Growth } \\
\text { Inflation }\end{array}$ & $\begin{array}{r}3.42 \\
-2.75\end{array}$ & $\begin{array}{l}.001 \\
.007\end{array}$ \\
\hline & Real Growth & .413 & .506 & .200 & .102 & Interest & -1.16 & .250 \\
\hline \multirow[t]{4}{*}{ Mar 70-Sep 90} & Nominal Growth & .228 & .784 & .270 & .097 & Interest & -1.13 & .262 \\
\hline & Inflation & .047 & .492 & .889 & .211 & Interest & 0.06 & .952 \\
\hline & Interest Rate & .043 & .061 & .000 & .554 & $\begin{array}{l}\text { Growth } \\
\text { Inflation }\end{array}$ & $\begin{array}{r}2.64 \\
-2.47\end{array}$ & $\begin{array}{l}.010 \\
.016\end{array}$ \\
\hline & Real Growth & .334 & .366 & .283 & .122 & Interest & -1.24 & .221 \\
\hline
\end{tabular}

Nominal Growth $=\Delta \log$ (nominal GDP) $=\Delta x_{t}$ Inflation $=\Delta \log$ (GDP deflator) $=\Delta \mathrm{p}_{\mathrm{t}}$

Interest Rate $=\Delta$ (Central Bank Rate), 
Table 11

Joint Significance Tests in VAR for Germany Income Growth, Inflation, M3 and the Central Bank Rate

(Quarterly, 3 lags)

$\begin{array}{lll}\text { Dependent } & \text { p-values for: } \\ \text { Period } & \underline{\text { Variable }} & \underline{\text { Income Growth }} \quad \underline{\text { Inflation }} \quad \underline{\text { Money }} \quad \underline{\text { Interest }} \quad \underline{\mathbf{R}^{2}}\end{array}$

Coeff.

$\underline{\text { Period }}$ Variable $\underline{\text { Income Growth Inflation }}$ Money Interest $\underline{\mathbf{R}^{2}}$

Sum on $\underline{\text { Statistic p-value }}$

Mar 70- Dec 95

$\begin{array}{lr}\text { Nominal Growth } & .201 \\ \text { Inflation } & .081 \\ \text { Money } & .611 \\ \text { Interest Rate } & .009 \\ \text { Real Growth } & .270 \\ & \\ \Delta \text { log (nominal GDP) }=\Delta x_{\mathrm{t}} \\ \text { GDP deflator) }=\Delta \mathrm{p}_{\mathrm{t}} \\ \text { 3) }=\Delta \mathrm{m}_{\mathrm{l}} \\ \text { Central Bank Rate) }\end{array}$

$\begin{array}{llll}.610 & .167 & .402 & .160 \\ .305 & .097 & .838 & .260 \\ .433 & .000 & .149 & .379 \\ .008 & .257 & .000 & .587\end{array}$

$\begin{array}{lrr}\text { Money } & 2.22 & .029 \\ \text { Interest } & -0.22 & .828 \\ \text { Money } & 0.95 & .346 \\ \text { Interest } & 0.36 & .720 \\ \text { Growth } & 0.45 & .653 \\ \text { Inflation } & 1.03 & .308 \\ \text { Growth } & 3.25 & .002 \\ \text { Inflation } & -3.16 & .002\end{array}$

Nominal Growth $=\Delta \log \left(\right.$ nominal GDP) $=\Delta x_{1}$

Inflation $=\Delta \log ($ GDP deflator $)=\Delta \mathrm{p}_{\mathrm{i}}$

Money $=\Delta \log (\mathrm{M} 3)=\Delta \mathrm{m}_{\mathrm{l}}$

Interest Rate $=\Delta$ (Central Bank Rate), 
Table 12

Joint Significance Tests in VAR for Germany

Income Growth, Inflation, M3 and the Central Bank Rate

(Quarterly, 3 lags)

$\begin{array}{lll}\text { Dependent } & \text { p-values for: } \\ \text { Period } & \underline{\text { Variable }} & \text { Income Growth }\end{array}$

Coeff.

Sum on t Statistic p-value

\begin{tabular}{|c|c|c|c|c|c|c|c|c|c|}
\hline \multirow[t]{10}{*}{ Mar 70-Sep 90} & \multirow[t]{2}{*}{ Nominal Growth } & \multirow[t]{2}{*}{.163} & \multirow[t]{2}{*}{.351} & \multirow[t]{2}{*}{.024} & \multirow[t]{2}{*}{.633} & \multirow[t]{2}{*}{.216} & Money & 3.10 & .003 \\
\hline & & & & & & & Interest & -0.16 & .876 \\
\hline & \multirow{2}{*}{ Inflation } & \multirow[t]{2}{*}{.193} & \multirow[t]{2}{*}{.346} & \multirow[t]{2}{*}{.114} & \multirow[t]{2}{*}{.771} & \multirow{2}{*}{.278} & Money & 0.87 & .387 \\
\hline & & & & & & & Interest & -0.03 & .975 \\
\hline & \multirow[t]{2}{*}{ Money } & \multirow[t]{2}{*}{.529} & \multirow[t]{2}{*}{.467 } & \multirow[t]{2}{*}{.004} & \multirow[t]{2}{*}{.015} & \multirow[t]{2}{*}{.437} & Growth & 0.90 & .373 \\
\hline & & & & & & & Inflation & 0.14 & .890 \\
\hline & \multirow[t]{2}{*}{ Interest Rate } & \multirow[t]{2}{*}{.128} & \multirow[t]{2}{*}{.020} & \multirow[t]{2}{*}{.107} & \multirow[t]{2}{*}{.000} & \multirow[t]{2}{*}{.593} & Growth & 2.21 & .031 \\
\hline & & & & & & & Inflation & -2.96 & .004 \\
\hline & \multirow[t]{2}{*}{ Real Growth } & \multirow[t]{2}{*}{.071} & \multirow[t]{2}{*}{.029} & \multirow[t]{2}{*}{.054} & \multirow[t]{2}{*}{.808} & \multirow[t]{2}{*}{.217} & Money & 2.70 & .009 \\
\hline & & & & & & & Interest & -0.14 & .886 \\
\hline
\end{tabular}

Nominal Growth $=\Delta \log \left(\right.$ nominal GDP) $=\Delta x_{1}$ Inflation $=\Delta \log ($ GDP deflator $)=\Delta \mathrm{p}_{\mathrm{t}}$

Money $=\Delta \log (\mathrm{M} 3)=\Delta \mathrm{m}_{\mathrm{t}}$

Interest Rate $=\Delta$ (Central Bank Rate $)_{\mathrm{t}}$ 
Figure 1

Low Frequency Component of Change in Velocity

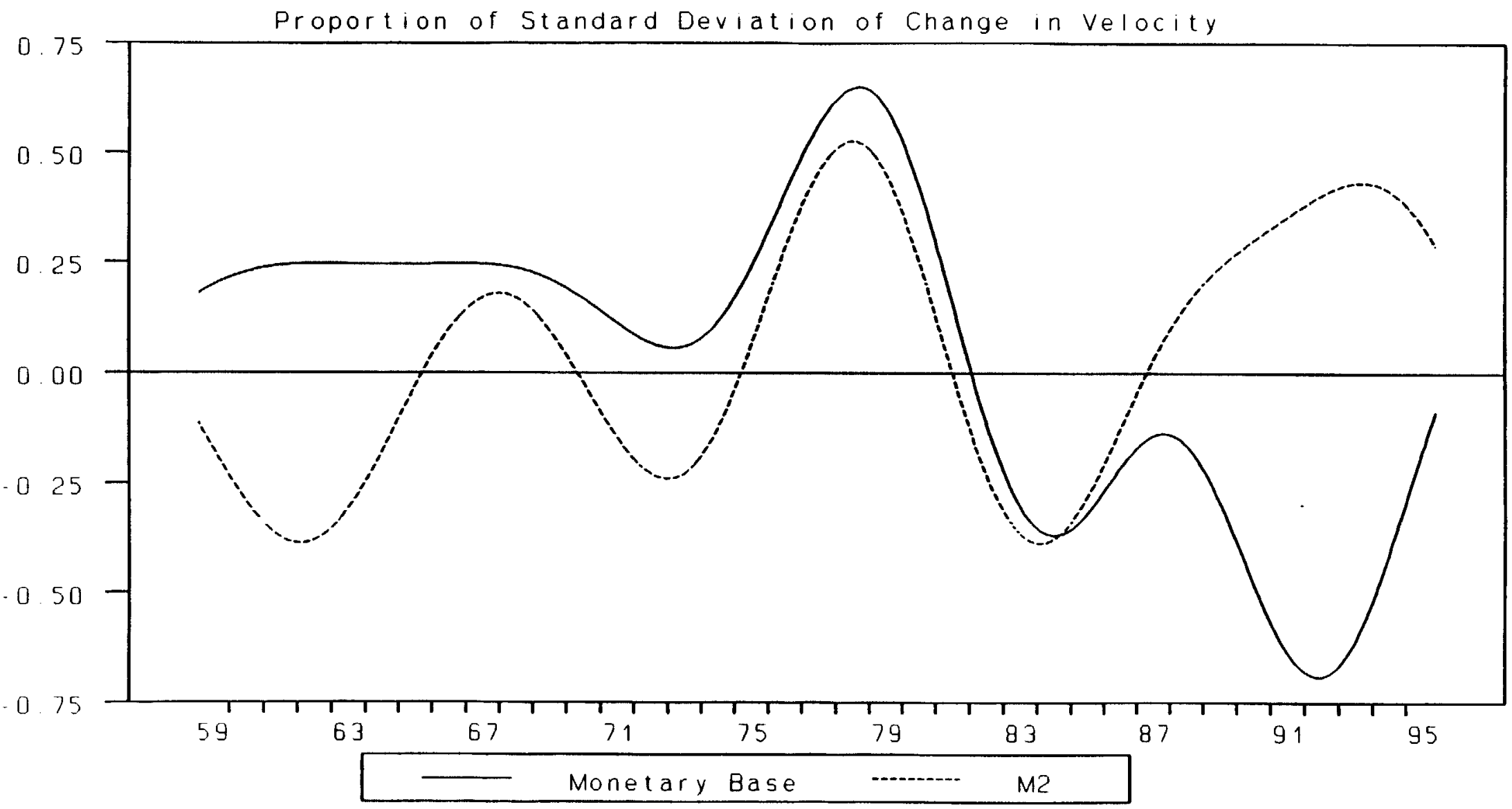




\section{Appendix}

Quarterly Results and VARs With Both Money and Interest Rates

Previous papers examining the relationship between monetary aggregates, income growth and inflation have typically focused on GNP/GDP and have therefore used quarterly data. To facilitate comparison of the results of this paper. with the earlier literature, tables A1 and A2 present quarterly results based on nominal GDP growth and the GDP deflator. In general, the results with quarterly data are less significant than the corresponding results with monthly data. The one exception is the significance of the monetary base in the equation for inflation in which low frequency components have been excluded from all three variables. The lags of the base are jointly significant and the sum of their coefficients is positive with a p-value of 0.001 ). These results suggest that there is information in the monetary base with regard to future inflation, not with regard to nominal GDP as the McCallum approach would require.

In the past, M1 has also been proposed as an instrument of monetary policy, although recent experience has been less encouraging than that for M2. Table A3 presents results from a VAR with monthly data for Ml growth, inflation and nominal income growth. The results tend to be less significant than those for M2 (e.g., table 3 in the text).

Table A4 illustrates the effects of including four-equations in a VAR with both money and interest rates. Qualitatively, the results are not very different from those obtained in the three-equation VARs. In the post- 1979 period, neither money nor the interest rate is significant in the equations for income growth and inflation, but income growth is significant in the equation for the federal funds rate. This suggests that the funds rate may have been used as an instrument of countercyclical policy to minimize fluctuations in income growth. 
Table A1

Joint Significance Tests in VAR with

Nominal Growth, Inflation and Monetary Base

(Quarterly, 3 lags)

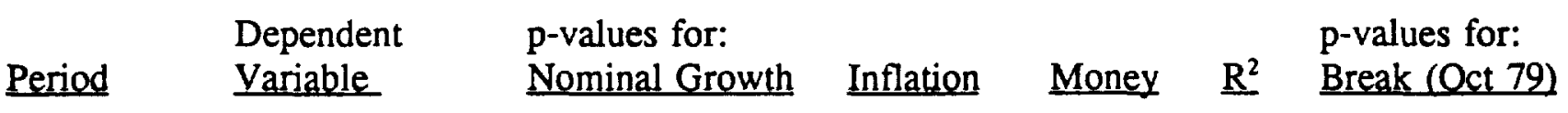

Q1 60- Q4 $95 \quad$ Nominal Growth

$\begin{array}{lllll}.031 & .518 & .249 & .171 & .004 \\ .955 & .000 & .164 & .672 & .006 \\ .337 & .508 & .000 & .560 & .069\end{array}$

Q4 79- Q4 95

Nominal Growth
Inflation
Money

.021

$.137 \quad .085 \quad .306$

.534

.000

$.091 \quad .764$

.225

.933

$.000 \quad .417$

Low Frequencies Excluded:

$\begin{array}{llllll}\text { Q4 79- Q4 95 } & \text { Nominal Growth } & .027 & .196 & .109 & .243 \\ & \text { Inflation } & .278 & .354 & .036 & .260 \\ & \text { Money } & .152 & .055 & .002 & .427\end{array}$

Nominal Growth $=\Delta \log$ (nominal GDP) $=\Delta x_{1}$

Inflation $=\Delta \log ($ GDP deflator $)=\Delta \mathrm{p}_{\mathrm{t}}$

Money $=\Delta \log \left(\right.$ BASE) $=\Delta \mathrm{m}_{\mathrm{t}}$ (quarterly average of monthly data) 
Table A2

Joint Significance Tests in VAR with

Nominal Growth, Inflation and M2

(Quarterly, 3 lags)

\begin{tabular}{|c|c|c|c|}
\hline ri & $\begin{array}{l}\text { Dependent } \\
\text { Variable }\end{array}$ & $\begin{array}{l}\text { p-values for: } \\
\text { Nominal Growth }\end{array}$ & Inflation \\
\hline
\end{tabular}

Q1 60- Q4 $95 \quad$ Nominal Growth

.592

$\begin{array}{llll}.690 & .000 & .256 & .244\end{array}$

Inflation

.933

.000

$\begin{array}{lll}.369 & .667 & .817\end{array}$

Money

.522

.390

$.000 \quad .564 \quad .032$

Q4 79- Q4 95

Nominal Growth

.073

.235

$.172 \quad .286$

Inflation

.478

.000

$.873 \quad .739$

Money

.130

$\begin{array}{lll}.694 & .000 \quad .527\end{array}$

Low Frequencies Excluded:

Q4 79- Q4 95

Nominal Growth
Inflation
Money

.051

.160

$.557 \quad .186$

.268

.662

$.943 \quad .143$

.196

.284

$.424 \quad .226$

Nominal Growth $=\Delta \log \left(\right.$ nominal GDP) $=\Delta x_{\imath}$

Inflation $=\Delta \log$ (GDP deflator) $=\Delta \mathrm{p}_{\mathrm{t}}$

Money $=\Delta \log (\mathrm{M} 2)=\Delta \mathrm{m}_{\mathrm{t}}$ (quarterly average of monthly data) 
Table A3

Joint Significance Tests in VAR with

Nominal Growth, Inflation and M1

(Monthly, 9 lags)

\begin{tabular}{|c|c|c|c|c|}
\hline$\pi^{\circ}$ & $\begin{array}{l}\text { Dependent } \\
\text { Variable }\end{array}$ & $\begin{array}{l}\text { p-values for: } \\
\text { Nominal Growth }\end{array}$ & Inflation & Money \\
\hline
\end{tabular}

Jan 60- Dec $95 \quad$ Nominal Growth

.000

$\begin{array}{llll}.016 & .227 & .275 & .016\end{array}$

Inflation

.001

.000

$\begin{array}{lll}.194 & .594 \quad .041\end{array}$

Money

.001

.028

$.000 \quad .362 \quad .013$

Oct 79- Dec $95 \quad$ Nominal Growth

.000

.159

$.910 \quad .300$

Inflation

.195

.000

$.615 \quad .626$

Money

.009

$\begin{array}{lll}.126 & .000 \quad .473\end{array}$

Low Frequencies Excluded:

Oct 79- Dec $95 \quad$ Nominal Growth

.000

.056

$.867 \quad .261$

Inflation

.117

$.007 \quad .418 \quad .347$

Money

.015

.313

$.000 \quad .414$

Nominal Growth $=\Delta \log ($ COIN $)+\Delta \log (\mathrm{CPI})=\Delta \mathrm{x}_{\mathrm{t}}$

Inflation $=\Delta \log (\mathrm{CPI})=\Delta \mathrm{p}_{\mathrm{\imath}}$

Money $=\Delta \log (\mathrm{M} 1)=\Delta \mathrm{m}_{\mathrm{t}}$ 
Joint Significance Tests in VAR with Nominal Growth, Inflation, M2 and the Federal Funds Rate (Monthly, 9 lags)

$\begin{array}{lll}\text { Dependent } & \text { p-values for: } \\ \text { Period } & \text { Variable } & \text { Nominal Growth Inflation }\end{array}$ Money Fed Funds $\underline{\mathbf{R}^{2}}$

$\begin{array}{lllllll}\text { Mar 60- Dec 95 } & \text { Nominal Growth } & .003 & .160 & .015 & .232 & .313 \\ & \text { Inflation } & .403 & .000 & .218 & .001 & .619 \\ & \text { Money } & .026 & .002 & .000 & .000 & .679 \\ & \text { Federal Funds } & .000 & .010 & .417 & .000 & .345 \\ \text { Oct 79- Dec 95 } & \text { Nominal Growth } & .007 & .336 & .742 & .934 & .334 \\ & \text { Inflation } & .872 & .000 & .321 & .057 & .665 \\ & \text { Money } & .432 & .029 & .000 & .002 & .695 \\ & \text { Federal Funds } & .001 & .114 & .809 & .000 & .449\end{array}$

Nominal Growth $=\Delta \log ($ COIN $)+\Delta \log (\mathrm{CPI})=\Delta \mathrm{x}_{\mathrm{t}}$ Inflation $=\Delta \log (\mathrm{CPI})=\Delta \mathrm{p}_{\mathrm{r}}$ Money $=\Delta \log (\mathrm{M} 2)=\Delta \mathrm{m}_{\mathrm{t}}$

Federal Funds $=\Delta$ (Federal Funds Rate) 